Pesq. Vet. Bras. 37(9):1002-1014, setembro 2017

DOI: $10.1590 / \mathrm{S} 0100-736 \mathrm{X} 2017000900017$

\title{
Thyroid hormones affect decidualization and angiogenesis in the decidua and metrial gland of rats ${ }^{1}$
}

\author{
Cíntia A. Souza², Juneo F. Silva ${ }^{3}$, Camila L.R. Silva ${ }^{4}$, Natália M. Ocarino ${ }^{5}$ \\ and Rogéria Serakides ${ }^{6 *}$
}

\begin{abstract}
Souza C.A., Silva J.F., Silva C.L.R., Ocarino N.M. \& Serakides R. 2017. Thyroid hormones affect decidualization and angiogenesis in the decidua and metrial gland of rats. Pesquisa Veterinária Brasileira 37(9):1002-1014. Universidade Federal de Minas Gerais, Av. Antonio Carlos 6627, Pampulha, Belo Horizonte, MG 31270-901, Brazil. E-mail: serakidesufmg@gmail.com

This study aimed to evaluate the effects of thyroid hormone on the decidua and metrial gland of rats and to examine the expression of angiogenic factors. 72 adult, female rats were divided into hypothyroid, $\mathrm{T}_{4}$-treated ${ }^{2}$, and control groups. At 10, 14 and 19 days of gestation (DG), the decidua and metrial gland were collected for histomorphometric and immunohistochemical evaluation of the expression of VEGF, Flk-1 and Tie-2. Hypothyroidism reduced the area of the decidua at 10 and 19 DG. Furthermore, VEGF was increased at 10 and 14 DG, and Flk-1 only at 14 DG, but both was reduced at 19 DG in the metrial gland without significantly changing the area occupied by blood vessels. Rats treated with $\mathrm{T}_{4}$ showed an increase in the decidua blood vessels at 10 and 19 DG. However, at 10 DG, excess $\mathrm{T}_{4}$ resulted in increased of Flk-1 in the decidua and metrial gland. Hypothyroidism increased the Tie-2 at 10 and 19 DG in the decidua and metrial gland. In conclusion, hypothyroidism reduces the area of the decidua and increases the expression of VEGF, Tie- 2 and Flk-1. The excess of $\mathrm{T}_{4}$ promotes tissue angiogenesis by increasing the number of vessels in the decidua because of the increased expression of Flk- 1 .
\end{abstract}

INDEX TERMS: Thyroid hormones, decidualization, angiogenesis, decidua, metrial gland, rats. thyroxine, PTU.

RESUMO.- [Hormônios tireoidianos afetam a decidualização e a angiogênese na decídua e glândula metrial de ratas.] Este estudo teve como objetivo avaliar os efeitos dos hormônios tireoidianos sobre a decídua e a glândula

\footnotetext{
${ }^{1}$ Received on August 6, 2016.

Acecepted for publication on January 25, 2017.

2 Programa de Pós-Graduação em Ciência Animal, Departamento de Clínica e Cirurgia Veterinária (DCCV), Escola de Veterinária, Universidade Federal de Minas Gerais (UFMG), Av. Antonio Carlos 6627, Pampulha, Belo Horizonte, MG 31270-901, Brazil.

${ }^{3}$ Setor de Morfologia, Departamento de Ciências Biológicas, Universidade Estadual de Santa Cruz, Campus Soane Nazaré de Andrade, Rodovia Jorge Amado, km 16, Salobrinho, Ilhéus, BA 45662-900, Brazil.

${ }^{4}$ Iniciação Científica, Setor de Patologia Animal, DCCV, Escola de Veterinária, UFMG, Av. Antonio Carlos 6627, Pampulha, Belo Horizonte, MG 31270-901, Brazil.

${ }^{5}$ Setor de Patologia Animal, DCCV, Escola de Veterinária, UFMG, Av. Antonio Carlos 6627, Pampulha, Belo Horizonte, MG 31270-901, Brazil.

${ }^{6}$ Setor de Patologia Animal, DCCV, Escola de Veterinária, UFMG, Av. Antonio Carlos 6627, Pampulha, Belo Horizonte, MG 31270-901, Brazil. *Corresponding author: serakidesufmg@gmail.com
}

metrial pela análise da expressão de fatores angiogênicos em ratas. 72 ratas adultas, fêmeas foram distribuídas nos grupos hipotiroideo, tratado com $\mathrm{T}_{4}$ e controle. Aos 10, 14 e 19 dias de gestação (DG), a decídua e a glândula metrial foram coletadas para avaliação histomorfométrica e imunoistoquímica da expressão de VEGF, Flk-1 e Tie-2. 0 hipotireoidismo reduziu a área da decídua aos 10 e 19 DG. Além disso, o VEGF aumentou aos 10 e 14 DG e o Flk-1 apenas aos 14 DG, mas ambos foram reduzidos aos 19 DG na glândula metrial sem alterar significativamente a área ocupada pelos vasos sanguíneos. As ratas tratadas com $\mathrm{T}_{4}$ apresentaram aumento do número de vasos sanguíneos na decídua aos 10 e 19 DG. Além disso, aos 10 DG, o excesso de $\mathrm{T}_{4}$ resultou no aumento de Flk-1 na decídua e na glândula metrial. 0 hipotireoidismo aumentou o Tie-2 em 10 e 19 DG na decídua e na glândula metrial. Desta forma, pode-se concluir que o hipotireoidismo reduz a área da decídua e aumenta a expressão de VEGF, Tie-2 e Flk-1. 0 excesso de $\mathrm{T}_{4}$ promove a angiogênese tecidual ao aumentar o número de vasos na decídua devido ao aumento da expressão de Flk-1. 
TERMOS DE INDEXAÇÃO: Hormônios tireoidianos, decidualização, angiogênese, decídua, glândula metrial, ratas, tiroxina, PTU.

\section{INTRODUCTION}

Angiogenesis at the maternal-fetal interface is critical to the proper development of the placenta and, therefore, the fetus (Reynolds et al. 2010). Changes in this process result in various pregnancy complications, such as preeclampsia, IUGR, miscarriage and stillbirth (Coulam 2000, Malassiné et al. 2003, Toder et al. 2003, Torry et al. 2004, Redmer et al. 2005, Zhang et al. 2007, Vonnahme et al. 2008, Soares et al. 2012).

The decidua, also known as the maternal placenta, it is important for both anchoring fetal placental tissue and coordinating, directly or indirectly, overall vascular remodeling at the maternal-fetal interface (Reynolds et al. 2010). Through the production of cytokines and growth factors, such as VEGF, angiopoietins (Ang) ${ }^{7}$ and placental growth factor $(\mathrm{PlGF})^{8}$ (Sherer 2001, Plaisier et al. 2007, Vonnahme et al. 2007, Seidenspinner et al. 2010), the decidual cells coordinate the replacement of the vascular endothelium of maternal uterine spiral arteries by the actions of trophoblast cells to establish the hemochorial placenta. During this process, there is a loss of the smooth muscle of arteries, vasodilation and increased blood flow (Ong et al. 2005, Harris et al. 2007). In rats, whose placenta is hemocorial and similar to that of humans, vascular remodeling occurs from the middle-third of pregnancy, a period that also coincides with the beginning of trophoblast cell migration towards the decidua (Pijnenborg et al. 1981, Ain et al. 2003, Caluwaerts et al. 2005, Vercruysse et al. 2006, Pijnenborg \& Vercruysse 2010, Soares et al. 2012). During this process, there are extensive invasion of the decidua by Natural Killer cells in close association of uterine spiral artery in both humans and rats (Chakraborty et al. 2011, Chazara et al. 2011). Similarly to humans, rat trophoblasts deeply invade the decidua, extending to the mesometrial triangle, different from mice in which the trophoblastic invasion is very limited and confined to the mesometrial decidua (Silva \& Serakides 2016).

However, although some similarities stimulate the use of the rat as a model for the study of maternal-fetal interface of human and primates (Enders \& Blankenship 1999, Georgiades et al. 2002, Shortman \& Liu 2002, Carter \& Enders 2004, Carter 2007, Carter \& Mess 2007, Dilworth \& Silbley 2013, Silva \& Serakides 2016), some differences exist in structure, placental development and some types of trophoblast cells between the human and rat placentas (Silva \& Serakides 2016). During the placentation, the fetal placenta of the rat is organized into placental labyrinth and junctional zone (layer spongiotrophoblast plus giant cell layer), different from the human placenta that is organized in villous placenta [cytotrophoblast (innermost) and syncytiotrophoblast (outermost)] and extravillous trophoblast (EVT). The EVT is similar to the rat invasive trophoblasts that migrate towards the decidua (Silva \& Serakides 2016). The volume of the decidua and of each layer of the fetal placenta changes according to gestational period. In murids, in the initial and middle thirds of gestation there is an increase in the volume in the layers of the placenta and the middle third to the end of a reduction, with a labyrinthine layer to become more prominent. Moreover, in murids there is an increase in fetal blood vessels in which the proportion of maternal blood space remains stable throughout gestation (Favaron et al. 2013). The interaction between the fetal blood vessels and the maternal vascular space in the rat has a labyrinthine organization. This region corresponds to the human placental villi that are surrounded by intervillous space through which maternal blood flows (Silva \& Serakides 2016). In this region, the relation between the trophoblast cells and the endothelium of the fetal vessels is hemomonochorial in human, while in the rat placenta is hemotrichorial, i.e., with one or three trophoblast layers, respectively (Furukawa et al. 2014).

Maternal hypothyroidism is known to result in low birth weight and placental abnormalities (Silva et al. 2012). By contrast, hyperthyroidism promotes an increase in the birth rate without affecting weight or fetal viability (Freitas et al. 2007). Hypothyroid rats exhibit compromised vasculature of the placental labyrinth and reduced trophoblastic expression of VEGF and its receptor Flk-1 by the end of pregnancy. Furthermore, there is a reduction in the expression of inducible nitric oxide synthase (iNOS) ${ }^{9}$ and intrauterine trophoblastic migration, which are important for vasodilation and intrauterine vascular remodeling (Silva et al. 2012, Silva et al. 2014, Silva et al. 2015). Silva et al. (2015) observed that hyperthyroidism reduces VEGF and Flk-1 expression in trophoblast cells at the end of pregnancy, which suggests that such changes might be related to preterm delivery that is exhibited by these rats (Kramer et al. 2005, Freitas et al. 2007, Andraweera et al. 2012). However, evaluations of decidualization and the expression of angiogenic factors in the decidua and metrial gland of animals with thyroid dysfunction remain poorly characterized. The decidua influences the entire process of placentation (Galton et al. 1999, Galton et al. 2001). Therefore, we hypothesized that the placental disc changes observed in rats with thyroid dysfunction (Silva et al. 2012, Silva et al. 2014, Silva et al. 2015) might reflect changes in the decidua and metrial gland.

This study aimed to investigate the effects of hypothyroidism and excess thyroxine in decidualization and the expression of the angiogenic factors VEGF, Flk-1 and Tie-2 by immunohistochemistry in the decidua and metrial gland from the middle-third of pregnancy in rats.

\section{MATERIALS AND METHODS}

This study was approved by the Ethics Committee for Animal Experimentation of the Universidade Federal de Minas Gerais (protocol number 239/11).

Animal handling and induction of thyroid dysfunction. A total of 72 two-month-old Wistar rats were housed in plastic cages ( 6 animals/cage), where they received commercial feed $(1.4 \%$

\footnotetext{
${ }^{7}$ Angiopoietins: Ang.

${ }^{8}$ Placental growth factor: PlGF.

${ }^{9}$ Inducible nitric oxide synthase: iNOS.
} 
calcium, $0.60 \%$ phosphorus and $22 \%$ protein) and water ad libitum. Rats were kept under conditions of 12 hours of light and 12 hours of dark.

After a period of 30 days to acclimatize the rats, they were separated randomly into the following three groups: control, hypothyroid and $\mathrm{T}_{4}$-treated ( $\mathrm{n}=24$ animals per group). The hypothyroid group received $1 \mathrm{mg} /$ animal PTU ${ }^{10}$ diluted in $5 \mathrm{ml}$ distilled water by orogastric gavage daily (Silva et al. 2004, Silva et al. 2012, Silva et al. 2013). Rats treated with $\mathrm{T}_{4}$ received $50 \mu \mathrm{g} / \mathrm{animal} /$ day L-thyroxine $^{11}$ (Serakides et al. 2001, Freitas et al. 2007, Silva et al. 2013) diluted in $5 \mathrm{ml}$ distilled water by orogastric gavage daily. The control group animals received distilled water in the same volume as the treated groups.

At five days after the onset of treatment, females in all groups were subjected to vaginal cytology (Marcondes et al. 2002) to monitor the estrous cycle. During the same period, six rats from each group were euthanized with an overdose of anesthetic to obtain blood samples and measure the levels of free $\mathrm{T}_{3}$ and $\mathrm{T}_{4}$.

Rats in proestrus and estrus were housed in plastic cages with adult rats for 12 hours. The next morning, vaginal smears were performed to detect the presence of sperm. When sperm were observed, copulation was confirmed and that day was designated as 0 DG. After copulation, female rats were housed individually in plastic cages. Animals in the control, hypothyroid and $\mathrm{T}_{4}$-treated groups continued with treatment as described above, until the day of euthanasia.

Blood sample collection and euthanasia. A total of six animals per group were killed on $0,10,14$ and 19 day of gestation (DG) with an anesthetic overdose. After anesthesia with xylazine $^{12}$ (5-10 mg/kg intramuscular) and ketamine ${ }^{13}$ (50-150mg/kg intramuscular), rats were subjected to blood sample collection by intracardiac puncture until death on 0 DG and 19 DG. Blood was collected into tubes with heparin to obtain plasma and stored at $-20^{\circ} \mathrm{C}$ for subsequent dosage-free $\mathrm{T}_{3}$ and $\mathrm{T}_{4}$ measurements. Measurements were performed using chemiluminescence ${ }^{14}$ on fully automatic methods or kits according to the manufacturer's recommendations.

Necropsy. After euthanasia at 10 DG, 14 DG, and 19 DG, the uterus and placenta containing fetuses were separated from the tube and ovary. Decidua along with metrial glands and placental discs of four sites of placental insertion per rat were fixed in cold $4 \%$ paraformaldehyde for 24 hours. Deciduas were process using a routine technique in paraffin and subjected to microtomy to obtain sections of $4 \mu \mathrm{m}$ on silanized slides for staining with hematoxylin and eosin (HE) and Masson's trichrome, or immunostaining was performed for VEGF, Flk-1 and Tie-2. Histological sections was always performed on the same transverse section, including the decidua, metrial gland and placental disc, to standardize the analysis sites.

Histomorphometric analysis. The decidua and metrial gland of the mesometrial region were studied. Histological sections of decidua were stained with H\&E or Masson's trichrome and enlarged $4 \mathrm{X}$ and 20X, respectively. Slides were photographed with a Spot Color Insight digital camera ${ }^{15}$ coupled to an Olympus BX-40 microscope. A total of decidua sections were assessed per rat. Using the program Image Pro Plus ${ }^{\circledR}$ version $4.5^{16}$, measurements were carried out over the total area occupied by decidua in histological sections stained with H\&E. The number of blood vessels and the area they occupied were determined in seven fields per decidua in Masson's trichrome-stained sections.

Immunohistochemistry. For immunohistochemistry, the streptavidin-biotin-peroxidase ${ }^{17}$ technique was used with antigen recovery using a retrieval solution at $98^{\circ} \mathrm{C}$. Histological sections were incubated in a humid chamber overnight with primary antibody, and then the following steps were carried out: blocking of endogenous peroxidase, blocking with serum (Ultra vision Block, Lab Vision Corp., Fremont, CA. USA) and streptavidin peroxidase incubation for 30 minutes per step. Anti-VEGF antibody (sc-152, Santa Cruz Biotechnology, CA, USA) was used at a dilution 1:100, while anti-Flk-1 (sc-6251, Santa Cruz Biotechnology, CA, USA) and anti-Tie2 (sc-9026, Santa Cruz Biotechnology, CA, USA) were used at dilutions of $1: 300$ and 1:50, respectively. Incubation with secondary antibody ${ }^{18}$ was performed for 45 minutes. As a chromogen, diaminobenzidine ${ }^{19}$ was used. Sections were counter-stained with Harris hematoxylin ${ }^{20}$. The negative control was obtained by replacing the primary antibody with IgG (X0909, Dako, CA, USA).

Descriptive and quantitative evaluations of the immunohistochemical expression of VEGF, Flk- 1 and Tie- 2 were performed in two decidua and metrial gland sections per rat for each group. The mesometrial decidua was divided into central and lateral regions at 10 DG (Herington et al. 2007); these factors were observed at the basal decidua and metrial gland, which were formed by the central spiral arteriole and its branches were surrounded by decidual and metrial gland cells (i.e., uNK cells, macrophages, dendritic cells and lymphocytes) at 14 DG and 19 DG (Croy 1999). To determine the intensity and immunostaining area, images were obtained using a Spot Color Insight digital camera ${ }^{15}$ coupled to an Olympus BX-40 microscope at 20X magnification. The intensity and area of immunostaining were determined using ImageJ $\mathrm{WCIF}^{\circledR}$ software $^{21}$. Color deconvolution and thresholding of images were carried out. Data were analyzed and expressed as the intensity (integrated density) of immunostaining and area in pixels (Silva et al. 2015).

Statistical analysis. The study used a completely randomized design. ANOVA was performed, and each variable was determined using means and standard deviation. Means were compared using the Student-Newman-Keuls test (SNK). Differences were considered significant if $\mathrm{p}<0.05$.

\section{RESULTS \\ Induction of thyroid dysfunction}

Rats treated with PTU exhibited lethargy and reduced plasma levels of $\mathrm{T}_{4}$ and free $\mathrm{T}_{3}$ compared with control animals at time zero $\left(\mathrm{T}_{4} \mathrm{P}<0.05\right.$ and $\left.\mathrm{T}_{3} \mathrm{P}<0.01\right)$ and at $19 \mathrm{DG}$ $\left(\mathrm{T}_{4}, \mathrm{P}<0.001 ; \mathrm{T}_{3}, \mathrm{P}<0.05\right)$, thereby confirming the induction of hypothyroidism (Fig.1A and 1B). By contrast, rats treated with $\mathrm{T}_{4}$ exhibited aggression and increased plasma levels of free $\mathrm{T}_{4}$ compared with controls on $0 \mathrm{DG}$ and $19 \mathrm{DG}$ (0 DG, $\mathrm{P}<0.001$; 19 DG, P<0.001; Fig.1B). However, levels of free $\mathrm{T}_{3}$ did not significantly increase in the group of rats treated with thyroxine.

\footnotetext{
${ }^{10}$ Sigma-Aldrich, St Louis, MO, USA.

${ }^{11}$ Sigma-Aldrich, St Louis, MO, USA.

${ }^{12}$ Kensol-Cloridrato de xilazina a 2\% (Laboratórios König, AvellanedaArgentina).

${ }^{13}$ Quetamina Injetável Vetnil, $10 \mathrm{mg} / \mathrm{mL}$ (Vetecia Laboratórios de Produtos Veterinários Ltda, Louveira, SP, Brasil).

${ }^{14}$ IMMULITE, Siemens Medical Solutions Diagnostics, Malvern, PA, USA.

${ }^{15}$ SPOTTM, Sterling Heights, MI, USA.

${ }^{16}$ Media Cybernetics- Roper Technologies- S\&P 500, Fortune 1000 and Russell 1000, New York, USA.

${ }^{17}$ Streptavidin Peroxidase, Lab Vision Corp., Fremont, CA, USA.

${ }^{18}$ Biotin Goat, Lab Vision Corp., Fremont, CA. USA.

${ }^{19}$ DAB substrate system, Lab Vision Corp., Fremont, CA. USA.

${ }^{20}$ Hematoxilina de Harris, Merck, Darmstadt, DE.

${ }^{21}$ Media Cybernetics Manufacturing, Rockville, MD, USA.

${ }^{22}$ Uterine natural killer cells: uNKs.
} 


\section{Histomorphometry}

In all groups at $10 \mathrm{DG}$, the decidua exhibited a central region with infiltration by trophoblast cells that were surrounded by decidual cells characterized by a rounded or polyhedral shape with an enlarged, finely granular and eosinophilic cytoplasm. The decidual cells were sometimes juxtaposed. Occasionally, some uterine natural killer cells (uNKs) ${ }^{22}$ were observed to be interspersed with decidual cells. The uNKs are characterized by a rounded shape with eosinophilic and/or basophilic cytoplasmic granules. In the lateral region of the decidua, poorly differentiated, spindle or stellate cells could be observed with a moderate cytoplasm that was loosely organized. This region was bounded by a thin layer of smooth muscle. During this period, the metrial gland was initiating its development with few uNKs around the blood vessels. In this gestational age, the hypothyroid group exhibited a smaller decidua area compared with the controls (Fig.2B and J; $\mathrm{P}<0.05$ ). In this group, there was no significant reduction in the number of blood vessels or the area occupied by vessels (Fig. 2K and 2L). By contrast, in the $\mathrm{T}_{4}$-treated group, there was no significant difference in the decidua area, although the number of blood vessels was significantly higher compared with the controls $(\mathrm{P}<0.01$; Fig.2C, 2J and 2L).

At 14 DG in all groups, smooth muscle between the myometrium and decidua basalis was present in the metrial gland. The decidua exhibited a predominance of decidualized endometrial cells that were ovoid or polyhedral, enlarged and with an eosinophilic and finely granular cytoplasm with an epithelioid arrangement. Among these cells, there were numerous blood vessels. In the central region from the decidua, there were large-caliber arterioles that penetrated the metrial gland, around which glycogen cells and interstitial trophoblast could be observed. Many uNKs were arranged concentrically around blood vessels of different sizes. The endovascular trophoblast was aligned, juxtaposed or sometimes loosely distributed within the vascular wall where it replaced endothelial cells. During next period of gestation, there were no significant differences between groups regarding the area of the decidua (Fig.2D, 2E, 2F and 2J) or the number and area occupied by blood vessels (Fig.2K and 2L).

At 19 DG, the decidua exhibited a greater amount of fibrous connective tissue and fewer decidual cells. The metrial glands had a reduced area compared to 14 DG, with an increased amount of glycogen cells and fewer uNKs. At 19 DG in the hypothyroid group, similar to what we observed at $10 \mathrm{DG}$, a significant reduction of decidua area compared with the controls was also observed (Fig.2G, 2H and 2J; $\mathrm{P}<0.05$ ), with no significant change in the number or area occupied by blood vessels $(\mathrm{P}<0.05$; Fig. $2 \mathrm{~K}$ and $2 \mathrm{~L})$. However, the $\mathrm{T}_{4}$-treated rats had an increase in the number of blood vessels compared with the controls $(\mathrm{P}<0.01$; Fig.2L).

\section{Immunohistochemical expression of VEGF, Flk-1 and Tie-2}

Expression of VEGF, Flk-1 and Tie- 2 could be detected by immunohistochemistry in the decidua and metrial gland
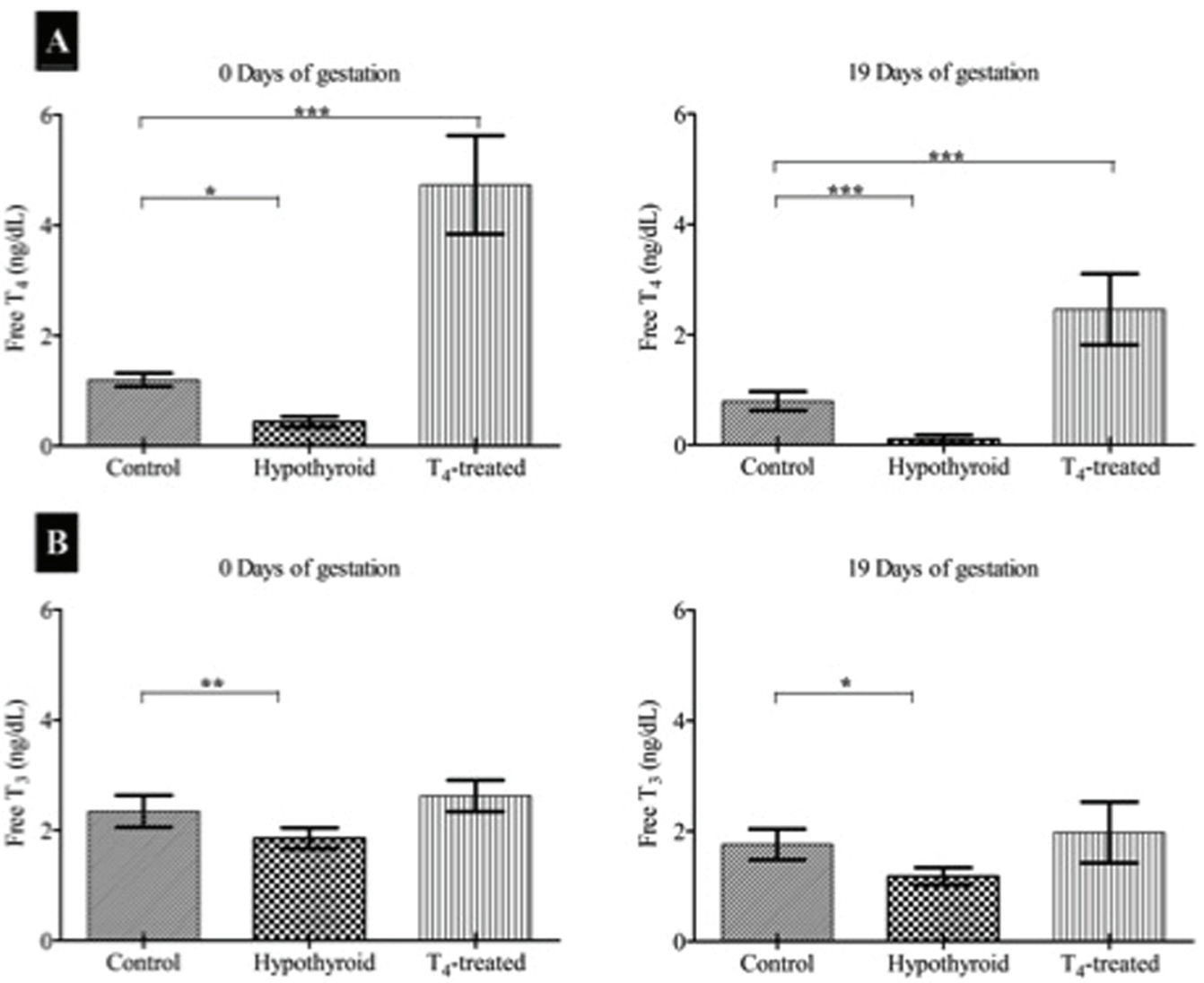

Fig.1. (A,B) Levels of $\mathrm{T}_{3}$ and free $\mathrm{T}_{4}$ (mean $\pm \mathrm{SD}$ ) in the plasma of rats from the control group, rats treated with $\mathrm{T}_{4}$, and hypothyroid rats on $0 \mathrm{DG}$ and $\left.19 \mathrm{DG}^{3}{ }^{*} \mathrm{P}<0.05 ;{ }^{* *} \mathrm{P}<0.01{ }^{* * *} \mathrm{P}<0.001\right)$. 

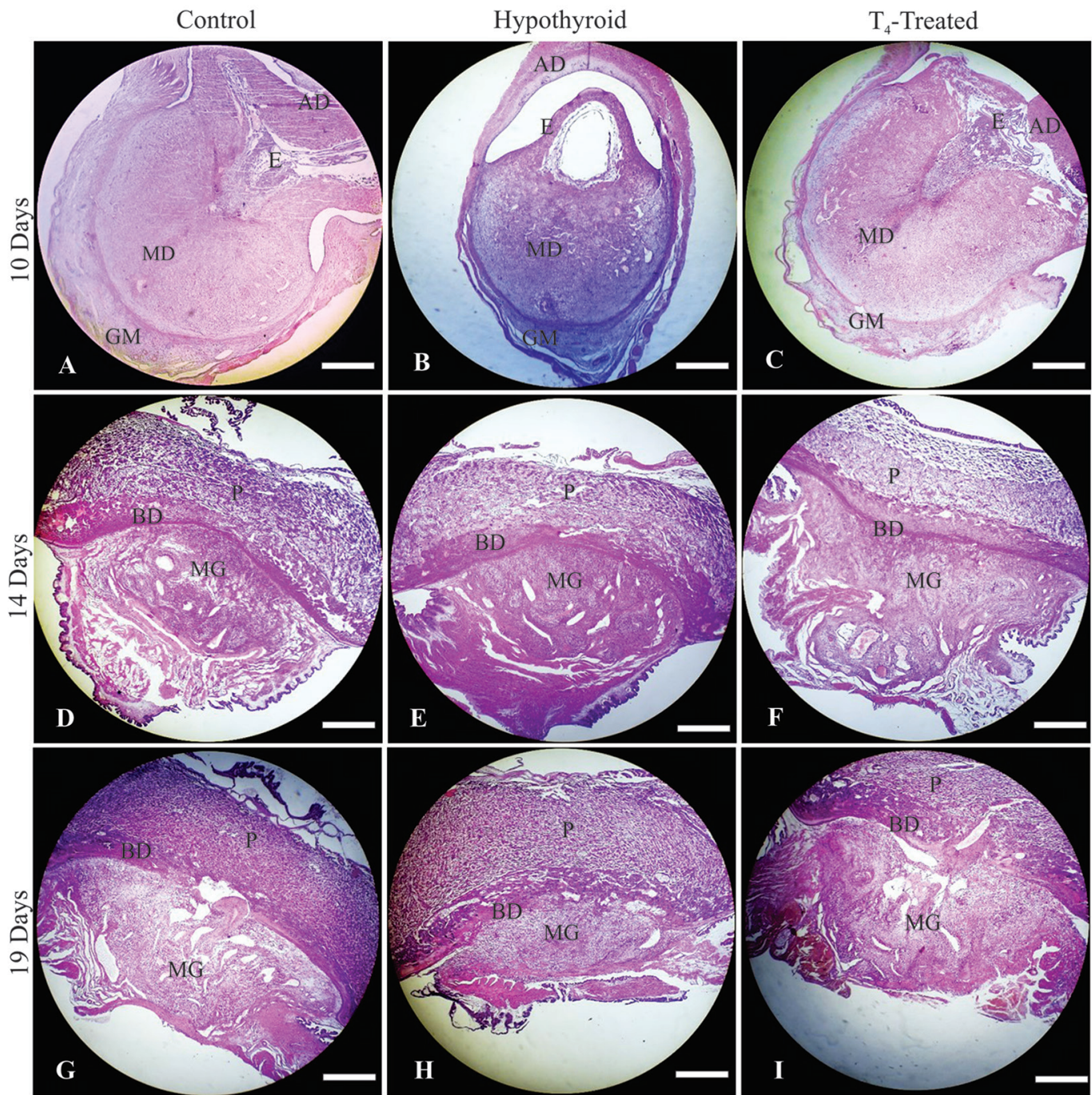

$\mathbf{J}$

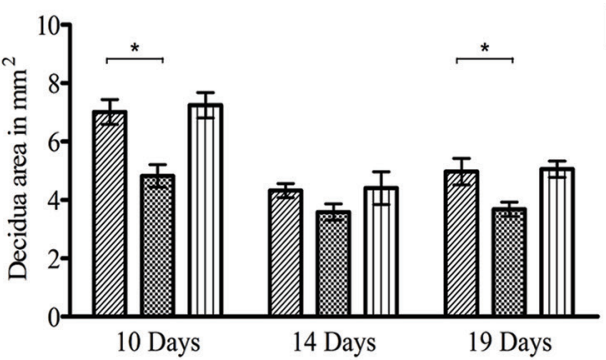

$\mathbf{K}$

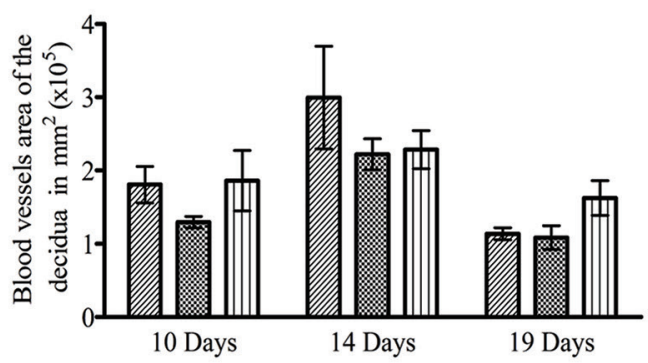

$\mathbf{L}$

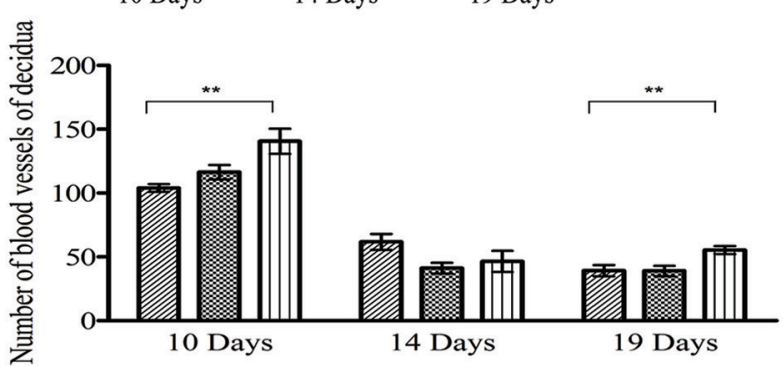

Fig.2. (A-I) Histological sections of the maternal-fetal interface of the control, hypothyroid and $\mathrm{T}_{4}$-treated groups at $10 \mathrm{DG}, 14 \mathrm{DG}$ and 19 DG. (J) Mesometrial decidua area of the control, hypothyroid and T -treated groups at 10 DG, 14 DG and 19 DG . Reduction of the decidua area in the hypothyroid group compared with the controls at 10 DG and 19 DG. (K) Area occupied by blood vessels in the BD of control, hypothyroid and $\mathrm{T}_{4}$-treated groups at 10 DG, 14 DG and 19 DG. (L) Number of blood vessels in the BD of the control, hypothyroid and $\mathrm{T}_{4}$-treated groups at $10 \mathrm{DG}, 14 \mathrm{DG}$ and $19 \mathrm{DG}$. Increase of the number of blood vessels in the BD of the $\mathrm{T}_{4}$-treated group compared with the control group at $10 \mathrm{DG}$ and $19 \mathrm{DG}\left({ }^{*} P<0.05\right.$; $\left.{ }^{* *} P<0.01\right)$. Haematoxylin Eosin stain. Bar $=1000 \mu \mathrm{m}$. Antimesometrial decídua (A,D); embryo (E); basal decidua (B,D); metrial gland (M,G); mesometrial decídua (M,D); placenta (P). 
of decidual cells, interstitial and endovascular trophoblast, uNKs, macrophages, fibroblasts and endothelial cells; expression was observed in each of the experimental groups. The area and intensity of expression varied according to the periods and differed between groups.

At 10 DG, hypothyroidism increased the area and intensity of VEGF immunostaining in the lateral area of the decidua compared with the controls $(\mathrm{P}<0.05$; Fig. $3 \mathrm{~A})$. Immunostaining could be observed in decidual cells in both the central and lateral regions, as well as in uNKs, interstitial macrophages, endothelial cells and interstitial trophoblasts. In the metrial gland, which is still undergoing development during this period, cytoplasmic VEGF immunostaining was visualized in uNKs, interstitial macrophages, endothelial cells and interstitial trophoblasts. Additionally, in the hypothyroid group, the VEGF immunostaining intensity in the decidua and metrial gland at 14 DG was significantly greater compared with the controls $(\mathrm{P}<0.01$; Fig.3B). Increased immunohistochemical expression of VEGF at 10 DG and 14 DG in the hypothyroid group was mainly observed in decidual cells and uNKs, despite being expressed by other cell types. From 10 to 14 DG, expression was observed in all experimental groups, but became significantly decreased in the intensity as well as the area of VEGF immunostaining $(\mathrm{P}<0.001$; Fig.3D).

By contrast, at $19 \mathrm{DG}$, a reduced VEGF immunostaining area was observed in the metrial glands of rats the hypothyroid group compared with the control group $(\mathrm{P}<0.05$; Fig.3C). Immunostaining was most evident in uNKs and macrophages, predominantly in perivascular areas. In this gestational age, as well as in other periods, the $\mathrm{T}_{4}$-treated rats showed no significant differences in VEGF expression in the decidua compared with the controls ( $\mathrm{P}>0.05$; Fig. $3 \mathrm{~A}$, $\mathrm{B}$ e C). Immunostaining of VEGF only increased in the control group at $14 \mathrm{DG}$ to $19 \mathrm{DG}(\mathrm{P}<0.01)$, i.e., there was no significant difference between periods in the hypothyroid and $\mathrm{T}_{4}$-treated groups of rats (Fig.3D).

Regarding the VEGF receptor, Flk-1, the rats treated with $\mathrm{T}_{4}$ showed an increase in the area and intensity of immunostaining in the central region of the decidua at $10 \mathrm{DG}$ compared with the control rats $(\mathrm{P}<0.05$; Fig.4A). Immunostaining was cytoplasmic and observed in decidual cells, endothelial cells, interstitial macrophages and uNKs in each of the experimental groups; however, immunostaining was more intense in the uNKs. Immunostaining of Flk-1 was predominantly observed in the cytoplasm of uNKs at 14 DG, and an increased intensity of immunostaining was observed in the decidua and metrial gland of the hypothyroid group compared with the control group $(\mathrm{P}<0.05$; Fig.4B). However, both the hypothyroid and $\mathrm{T}_{4}$-treated groups exhibited reduced immunohistochemical expression of Flk-1 in the decidua and metrial gland compared with the control rats at $19 \mathrm{DG}(\mathrm{P}<0.05$; Fig.4C). When the periods of gestation were compared within each group, we observed that there was less immunostaining of Flk-1 in both treatment groups at $14 \mathrm{DG}$ to $19 \mathrm{DG}$ (hypothyroid, $\mathrm{P}<0.001 ; \mathrm{T}_{4}$-treated, $\mathrm{P}<0.05)$, which did not occur in the control group (Fig.4D). Furthermore, an increased area $(\mathrm{P}<0.05)$ and density $(\mathrm{P}<0.01)$ of immunostaining in the hypothyroid group at 10 DG to 14 DG were observed, which did not occur in the control or $\mathrm{T}_{4}$-treated groups (Fig.4D).

In relation to Tie-2 (angiopoietin receptor), cytoplasmic immunostaining was observed in decidual cells, endothelial cells, interstitial macrophages and uNKs in all of the experimental groups. Immunostaining was most intense in decidual cells. There was an increase in immunostaining intensity in the lateral region of the mesometrial decidua in the hypothyroid compared with the control group at $10 \mathrm{DG}(\mathrm{P}<0.05$; Fig. 5A). At $14 \mathrm{DG}$, there was no significant difference between groups. At 19 DG, hypothyroid rats exhibited a significant increase in the area and intensity of Tie-2 expression, predominantly in decidual cells of the decidua and metrial gland compared with control rats $(\mathrm{P}<0.01$; Fig. $5 \mathrm{~B})$. The $\mathrm{T}_{4}$-treated rats showed no differences in Tie-2 immunostaining in the decidua compared with control rats in all of the gestational periods $(\mathrm{P}>0.05$; Fig.5A, B e C). Comparing the gestation periods within each group, we observed that from 10 DG to 19 DG and from 14 DG to $19 \mathrm{DG}$, there was a marked reduction in Tie2 immunostaining in the control $(\mathrm{P}<0.05)$, hypothyroid $(\mathrm{P}<0.001)$, and $\mathrm{T}_{4}$-treated $(\mathrm{P}<0.001)$ groups (Fig. $\left.5 \mathrm{D}\right)$. Between 10 DG and 14 DG, the Tie-2 immunostaining area was only significantly reduced in the hypothyroid group ( $\mathrm{P}<0.001$; Fig. 5D).

\section{DISCUSSION}

Our findings revealed for the first time that thyroid dysfunction affected decidualization and angiogenesis in the decidua and metrial gland of rats in the mid- to late-gestation period by different mechanisms and was dependent on gestational age.

In this present study, there was a reduction in the serum levels of $\mathrm{T}_{3}$ and $\mathrm{T}_{4}$ after the administration of PTU. This occurred because PTU binds to thyroid peroxidase, which inhibits the conversion of iodide to iodine. Another action of PTU is to block the conversion of $\mathrm{T}_{4}$ to $\mathrm{T}_{3}$, the active form of the hormone, in target tissues by inhibiting the enzyme 5 '-deiodinase (Chakraborty et al. 2012). In this way, PTU effectively inhibits the synthesis of thyroid hormones (Holsberger et al. 2003, Jahnke et al. 2004, Chakraborty et al. 2012). However, in the $\mathrm{T}_{4}$-treated rats there was increased $\mathrm{T}_{4}$ without a concomitant increase in $\mathrm{T}_{3}$, but the increase in $\mathrm{T}_{4}$ was associated with excitability. According to Hennemann (2006), hyperthyroidism can overactive the thyroid with consequent elevation of serum $\mathrm{T}_{3}$ - and $\mathrm{T}_{4}$ - associated clinical signs. Thyrotoxicosis involves increased thyroid hormones resulting from many other causes that include iatrogenic effects associated with clinical and/or biochemical changes (Hennemann 2006). Therefore, it is not surprising that the $\mathrm{T}_{4}$-treated rat group exhibited thyrotoxicosis. In this case, increased $T_{4}$ without increased $T_{3}$ may have occurred because of the conversion of $\mathrm{T}_{4}$ to $\mathrm{T}_{3}$, which occurs predominantly in the cytoplasm of target cells by the actions of deiodinases (Gereben et al. 2008, Zanatta et al. 2013, Ramos et al. 2014). Another hypothesis is that $T_{3}$ has been rapidly metabolized and does not have time to increase overall serum levels. This occurs because pregnant females have a faster metbolism, along with an increased 
A

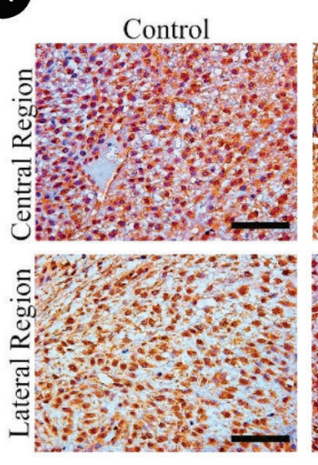

B
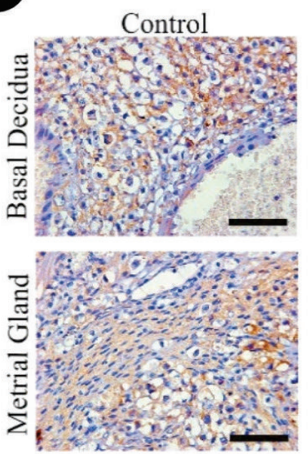

C

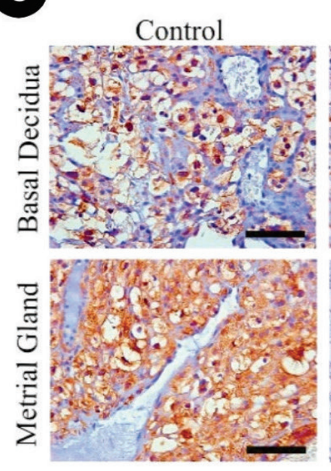

10 DAYS
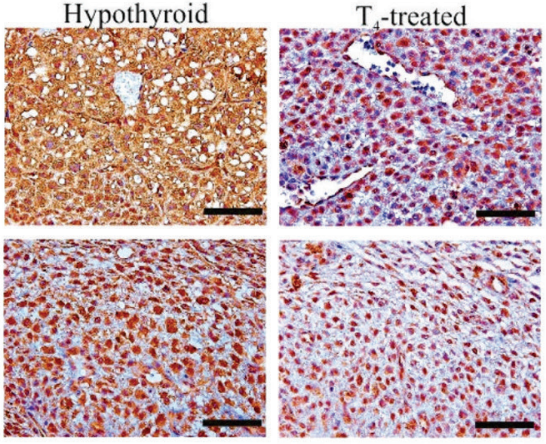

14 DAYS
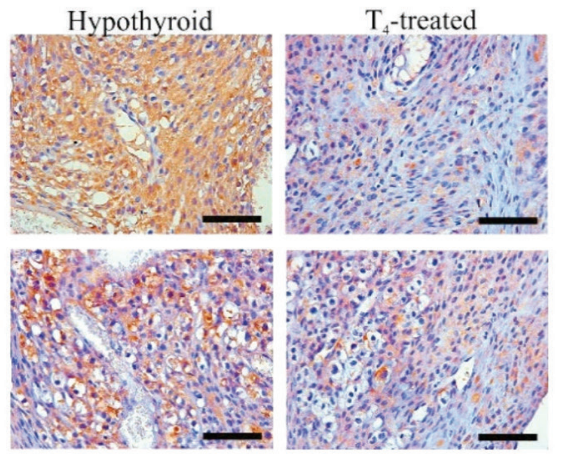

19 DAYS
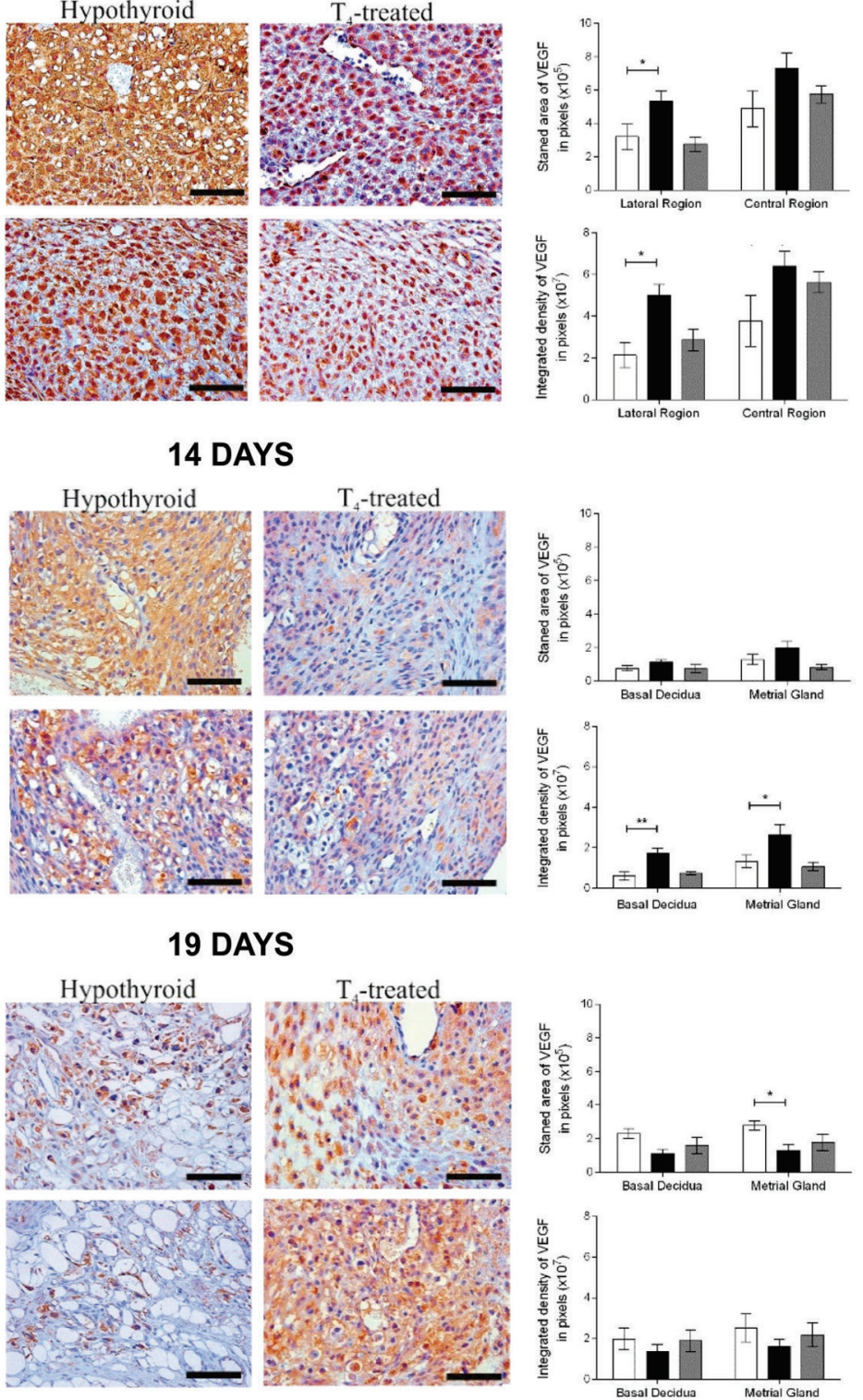

\section{(D)}

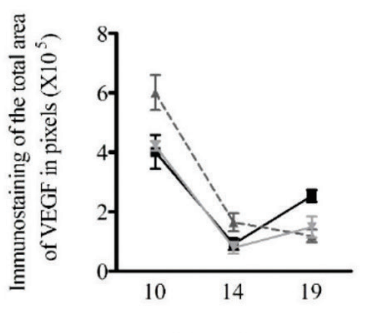

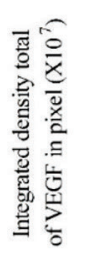

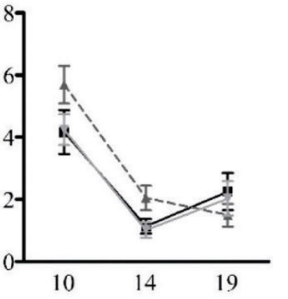

$\rightarrow$ Control $\quad$ - Hypothyroid $\rightarrow \mathrm{T}_{4}$-treated

Fig.3. VEGF expression in the decidua of rats of the control, hypothyroid and $\mathrm{T}_{4}$-treated. (A) Immunohistochemical expression of VEGF in the decidua at 10 DG with increased area and intensity of VEGF immunostaining in the lateral region of the decidua of the hypothyroid group compared with the control group. (B) Immunohistochemical expression of VEGF in the decidua at 14 DG with increased VEGF immunostaining intensity in the decidua and metrial gland in the hypothyroid group compared with the control group. (C) Immunohistochemical expression of VEGF in the decidua at 19 DG with reduction of VEGF immunostaining area in the metrial gland in the hypothyroid group compared with the control group $\left({ }^{*} \mathrm{P}<0.05\right.$; streptavidin-biotin-peroxidase counter-stain hematoxylin, Bar=200 $\mu \mathrm{m}$ ). (D) Immunostaining intensity and area of VEGF expression in the decidua of rats 10 DG, 14 DG and 19 DG, differences between periods in each group are noted. 
A

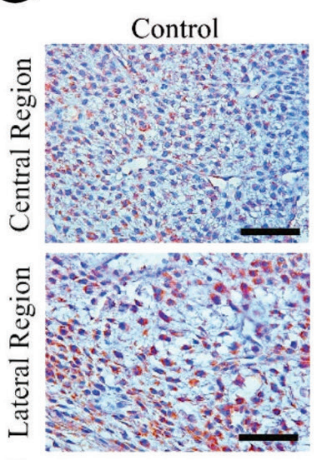

B
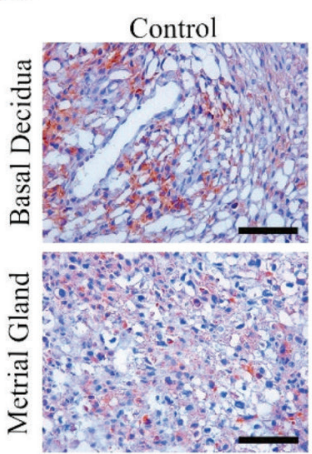

(C)
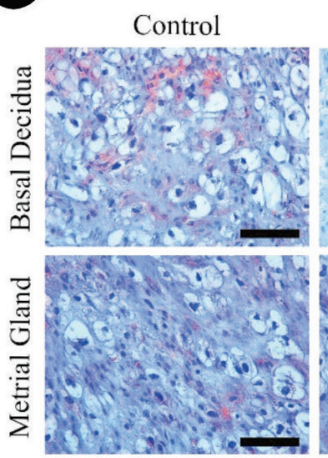

(D)
10 DAYS

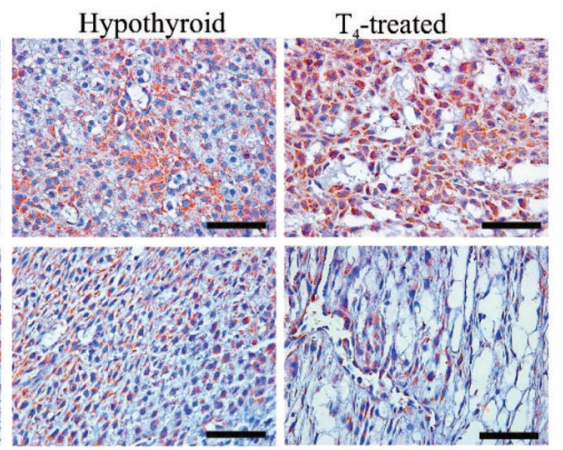

14 DAYS

Hypothyroid
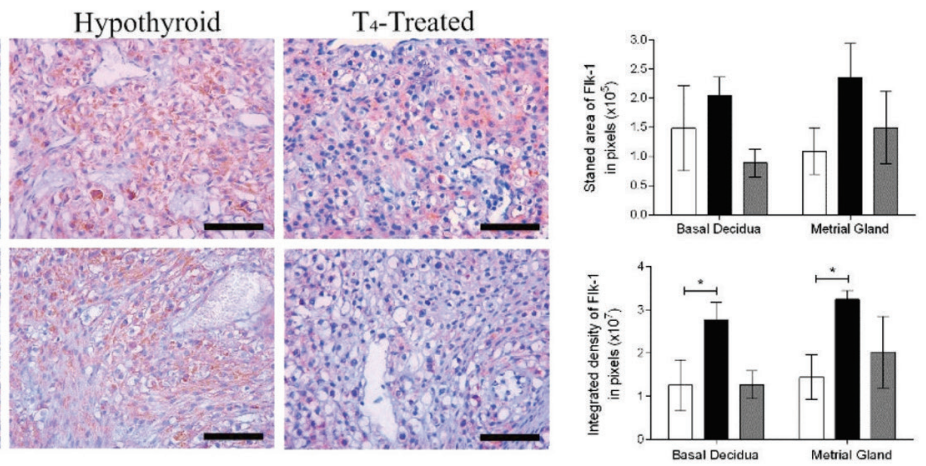

19 DAYS

Hypothyroid
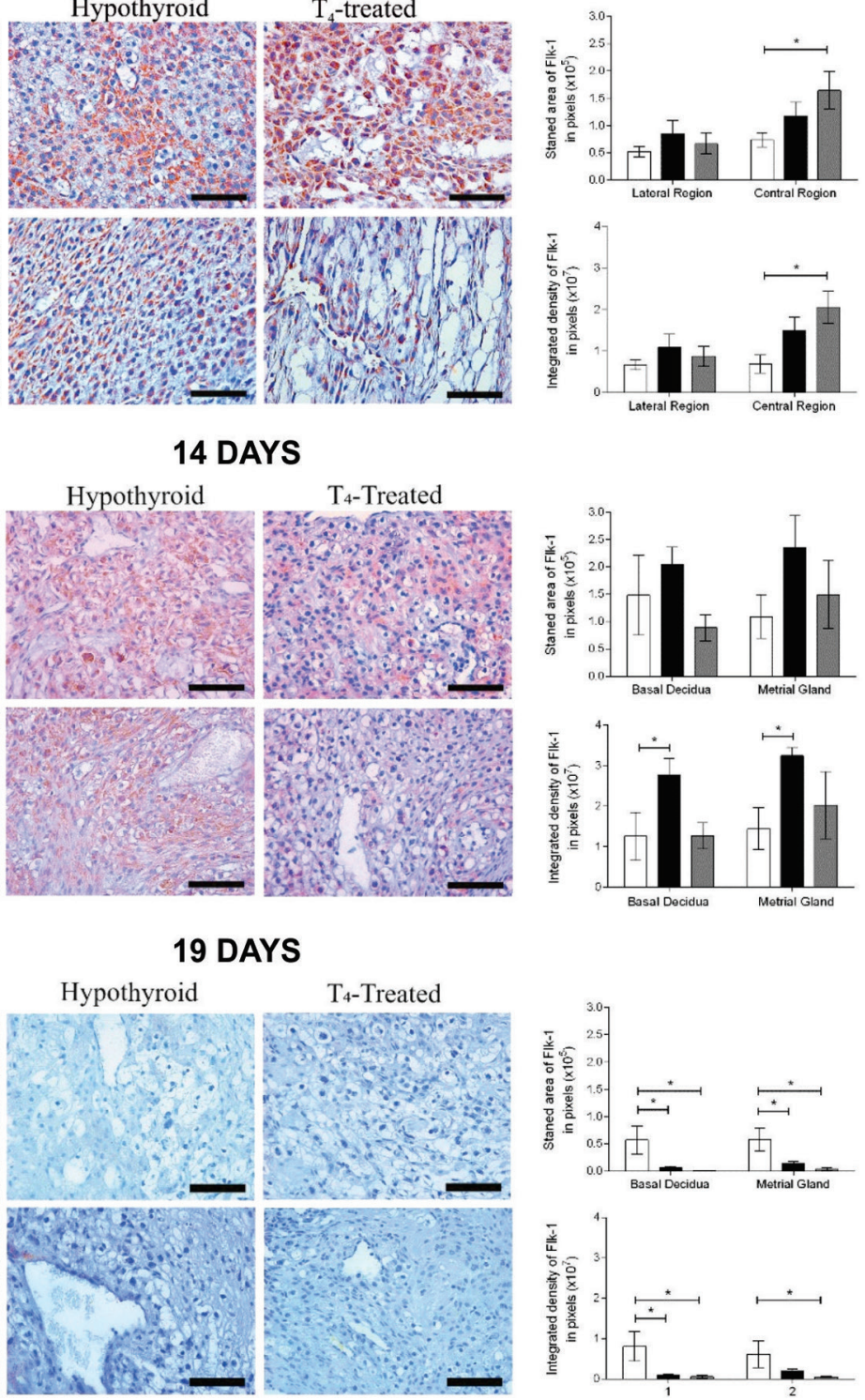
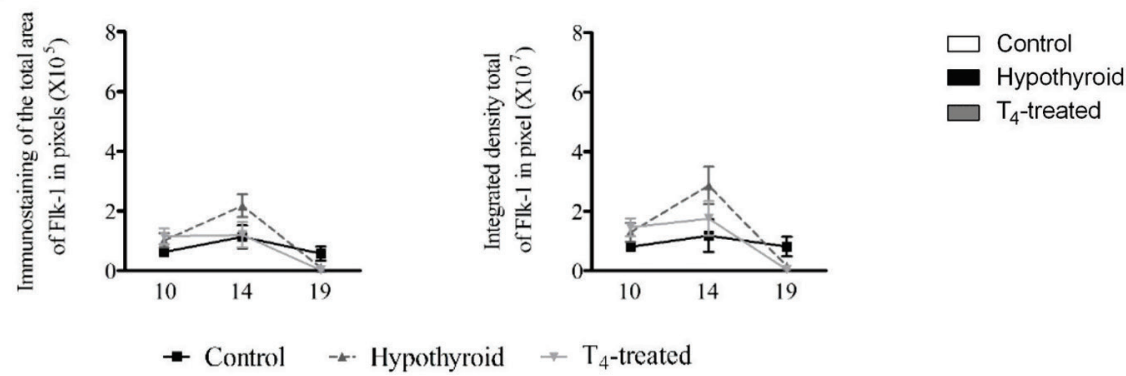

Fig.4. Flk-1 expression in the decidua of rats of the control, hypothyroid and $\mathrm{T}_{4}$-treated. (A) Immunohistochemical expression of Flk-1 in the decidua at $10 \mathrm{DG}$ with increase in the intensity and immunostaining area of Flk-1 in the central mesometrial decidua in the $\mathrm{T}_{4}$-treated group compared with the control group. (B) Immunohistochemical expression of Flk-1 in the decidua at 14 DG with increased immunostaining intensity of Flk-1 in the decidua and metrial gland in the hypothyroid group compared with the control group. (C) Immunohistochemical expression of Flk-1 in the decidua at 19 DG with reduction in the intensity and immunostaining area of Flk-1 in the decidua and metrial gland in tissues from the hypothyroid and $\mathrm{T}_{4}$-treated groups compared with the control group ( ${ }^{*} \mathrm{P}<0.05$; streptavidin-biotin-peroxidase counter-stain hematoxylin, Bar $\left.=200 \mu \mathrm{m}\right)$. (D) Immunostaining intensity and area of Flk-1 expression in the decidua of rats 10 DG, 14 DG and 19 DG, differences between periods in each group are noted. 
A

\section{DAYS}
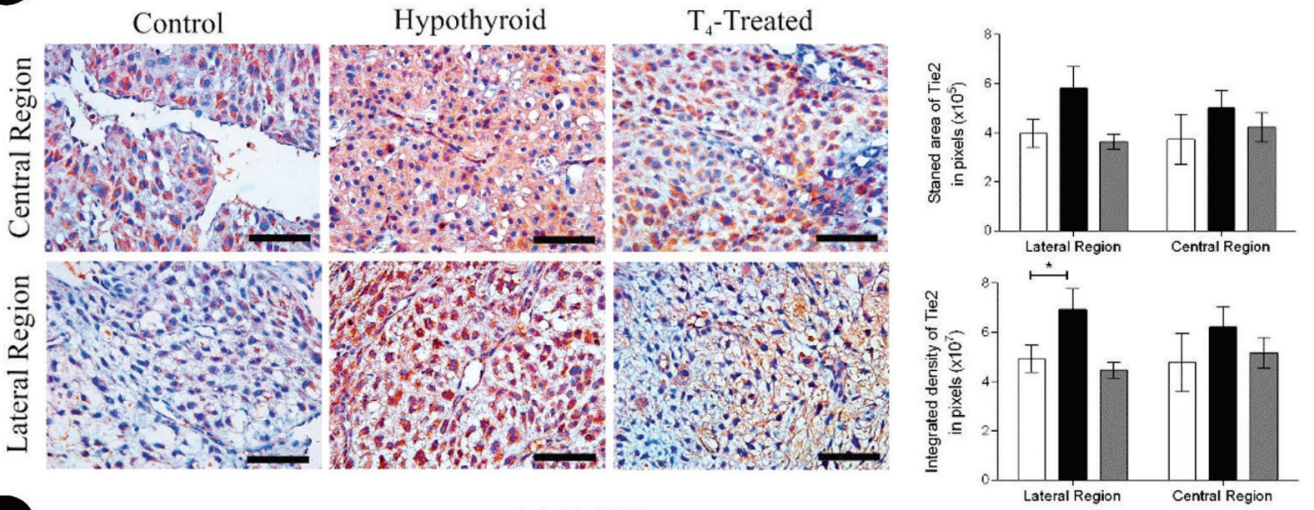

B

14 DAYS

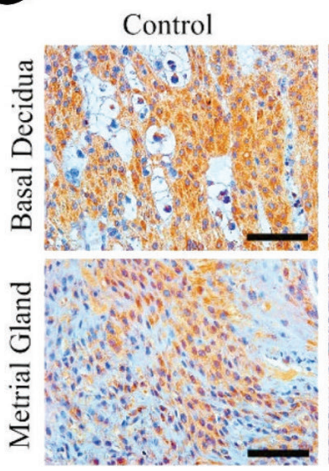

Hypothyroid

$\mathrm{T}_{4}$-Treated
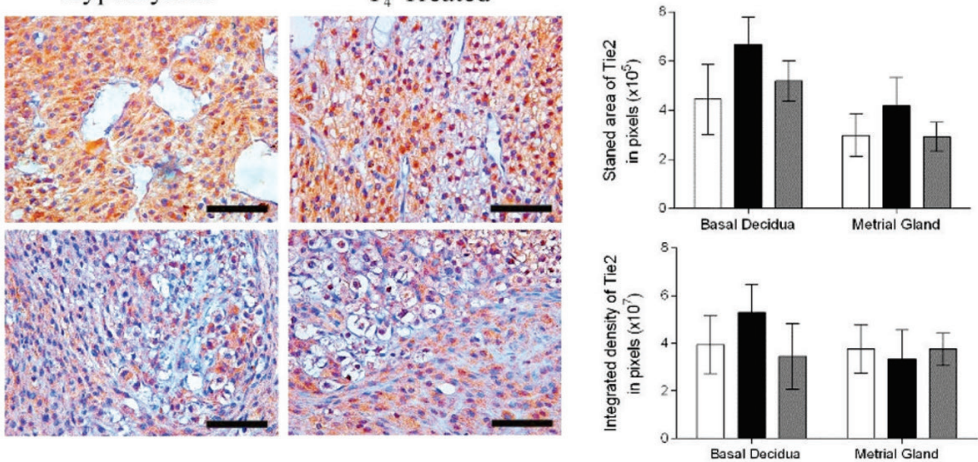

C

19 DAYS

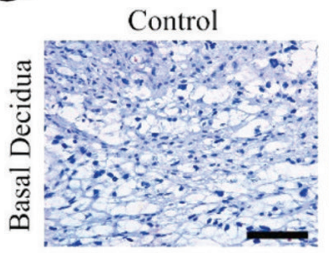

Hypothyroid
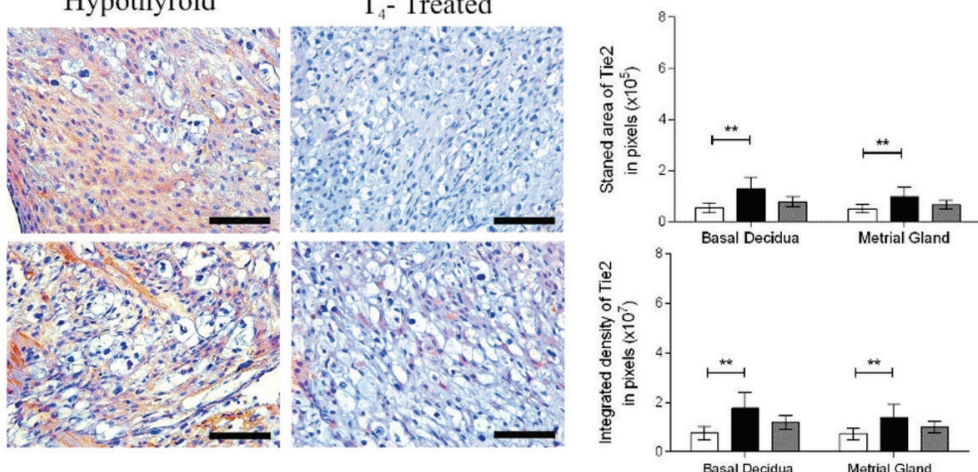

D
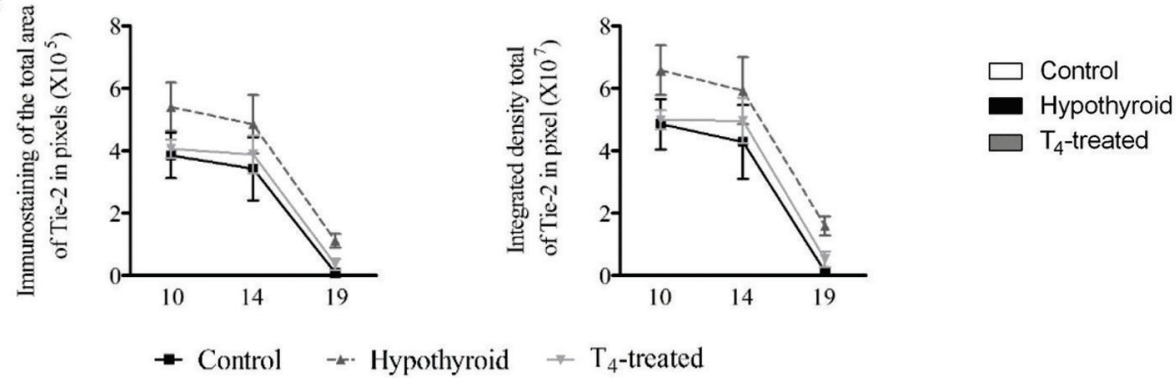

Fig.5. Tie-2 expression in the decidua of rats of the control, hypothyroid and $\mathrm{T}_{4}$-treated. (A) Immunohistochemical expression of Tie-2 in the decidua at 10 DG with increased Tie-2 immunostaining intensity in the lateral region of the mesometrial decidua from the hypothyroid group compared with the control group. (B) Immunohistochemical expression of Tie-2 in the decidua at 14 DG with there were not significant changes between groups. (C) Immunohistochemical expression of Tie-2 in the decidua at 19 DG with increased intensity and area of Tie-2 immunostaining in the basal decidua and metrial gland of tissues from the hypothyroid group compared with the control group $\left({ }^{*} \mathrm{P}<0.05\right.$; streptavidin-biotin-peroxidase counter-stain hematoxylin, Bar=200 $\left.\mu \mathrm{m}\right)$. (D) Immunostaining intensity and area of Tie-2 expression in the decidua of rats 10 DG, 14 DG and 19 DG, differences between periods in each group are noted. 
cardiac output, renal blood flow and glomerular filtration rate (Frederiksen 2001).

The reduction in the area of the decidua caused by hypothyroidism may occur because of the delay in the differentiation of interstitial fibroblasts to decidual cells in the absence of trophic stimulation by thyroid hormones (Kennedy \& Doktorcik 1988, Galton et al. 2001). The decidua is a highly specialized area that forms during pregnancy and initiates its progressive regression during the middle of gestation until delivery and slightly thereafter. The reduction in this area can affect the proper development of the placenta (Ashkar \& Croy 1999). This change could be involved in the genesis of low birth weight and placental changes observed in rats with hypothyroidism and in rats treated with the same PTU doses used in this present study (Silva et al. 2012).

Interestingly, despite a reduction in the area of the decidua, hypothyroidism increased VEGF and Tie- 2 expression in the lateral region of the mesometrial decidua during the first third of gestation without changing the number of blood vessels. It is known that the process of neovascularization and vascular remodeling in the maternal-fetal interface occurs intensely during the middle period of gestation to support blood flow in the developing fetus and to allow for the proper formation of the placenta (Plaisier 2011). Tie-2 is the receptor of angiopoietins 1 and 2, which exert antagonistic actions. Ang-1 promotes vascular stability and increases the diameter of blood vessels. However, Ang-2 expression can be induced by hypoxia, reduces adhesion between endothelial cells and increases the vascular diameter to yield a more complex vasculature and increase the number of branches (Plaisier 2011). Thus, based on the fact that Tie-2, when stimulated by Ang-1, promotes vascular stability (Plaisier 2011), our hypothesis is that its increase to $10 \mathrm{DG}$ in hypothyroid rats can slow vascular remodeling.

Vascular remodeling is characterized by the processing of blood vessels in the mesometrial decidua region (Pijnenborg et al. 1980). The uterine spiral arteriole passes from fine vessels and prominent muscles to dilated vessels, which are flabby and do not have maternal vasomotor control (Pijnenborg et al. 1980, Smith et al. 2009). This process is accompanied by the loss of smooth muscles in arteries and endothelial cells, which are replaced by extravillous trophoblasts and are supported on a fibrinoid amorphous matrix (Pijnenborg et al. 1980, Smith et al. 2009, Plaisie 2011). A delay in vascular remodeling in the decidua region can occur in early pregnancy and is associated with hypoxia and placental stress (Jauniaux et al. 2000, Myatt \& Cui 2004, Plaisier et al. 2007, Douglas et al. 2009, Plaisier 2011). Previous studies have demonstrated that hypoxia stimulates VEGF expression induced by hypoxia inducible factor $1 \alpha(H I F 1 \alpha)$ expression (Adelman \& Gertssenstein 2000, Plaisier 2011). During early gestation, there are periods of hypoxia with high VEGF expression until 10 DG. After this period, at 14 DG there is a reduction in VEGF expression in all experimental groups, as we observed in this present study, which can be explained by a reduction in hypoxia, which also occurs physiologically (Plaisier 2011). Furthermore, from 14 DG, the decidua begins its regression
(Picut et al. 2009). Another important factor observed by Silva et al. (2014) was the reduction of trophoblastic invasion of the maternal-fetal interface occurred in hypothyroid rats. Reduced intrauterine trophoblastic migration results in impaired vascular remodeling, hypoxia and placental stress (Lala \& Chakraborty 2003, Plaisier 2011, James et al. 2012). Importantly, decidual cells promote a uterine environment that is resistant to oxidative stress (Adelman et al. 2000, Red-Horse \& Zhou 2004, Plaisier 2011). Changes in decidual cell populations and the pattern of gene expression are related to the reduction of the area of decidua (Ashkar \& Croy 1999), as we observed in the hypothyroid group. Hence, a reduced decidual area can also cause hypoxia and placental stress. Therefore, it has been suggested that a hypoxic environment can promote not only increased VEGF expression at 10 DG in hypothyroid rats but also the expression of VEGF and its Flk-1 receptor at 14 DG. This occurs because Flk-1 expression is self-regulated and stimulated by VEGF (Plaisier et al. 2007, Douglas et al. 2009, Plaisier 2011, Kim et al. 2013).

Another hypothesis to explain the increase in VEGF expression at $10 \mathrm{DG}$ and $14 \mathrm{DG}$ in decidual cells in hypothyroid animals is that retention of this protein in the cytoplasm occurs because of a failure in the release mechanism. Rats with hypothyroidism have a defect in the formation of the cytoskeleton in neurons and astrocytes, which causes the retention of protein synthesis products in the cytoplasm of these cells (Cheng et al. 2010), and might have occurred during decidua development. However, more research will be need to confirm this hypothesis.

Although increased VEGF expression in $\mathrm{T}_{4}$-treated rats was not observed, there was an increase in Flk-1 expression at 10 DG. The increase in Flk-1 expression may lead to greater activity of both PIGF and VEGF, which favors vascular permeability and/or increased vessel formation (Plaisier et al. 2007, Plaisier 2011, Vasilopoulou et al. 2014). Importantly, rats with excess $\mathrm{T}_{4}$ exhibited a greater number of blood vessels in the region of decidua at 10 DG and 19 DG. It is possible that increased expression of Flk-1 in decidual cells may result from the paracrine stimulation of interstitial VEGF synthesized by trophoblast cells, as Silva et al. (2015) demonstrated increased expression of VEGF and PIGF in trophoblastic cells of the placental disk of $\mathrm{T}_{4}$-treated rats at $10 \mathrm{DG}$. Increased VEGF acts through its receptor in the middle stage of gestation to promote hematotrophic support to the fetus (Reynolds et al. 2010). This could partially explain why the increased number of viable fetuses with a uniform weight can be observed in hyperthyroid pregnant rats (Freitas et al. 2007).

The reduction of VEGF and Flk-1 in the decidua of the hypothyroid group at 19 DG corroborates the findings of Silva et al. (2015) who described reduced VEGF expression in the placental disc at $19 \mathrm{DG}$, in addition to increased gene expression of protein related to proliferin ( $r P l f)$, an anti-angiogenic factor. It is thought that the low expression of these factors can also favor low placental and fetal weights, which were exhibited by these animals (Smith et al. 2009, Silva et al. 2015), as the greatest increase in the body weight of a fetus occurs during the late stages of gestation (Baker 
et al. 1993). However, the greatest expression of Tie-2 in hypothyroid animals at 19 DG can also promote a delay in delivery, which was observed in animals with hypothyroidism (Hapon et al. 2003, Pickard et al. 2003). At the end of gestation, there is a reduction in the expression of Ang-2. Moreover, the process of early vascular regression at the maternal-fetal interface is necessary for the occurrence of delivery (Yuan \& Lin 2004). As Ang-2 promotes protection of the microvasculature and delayed apoptosis of endothelial cells (Yuan \& Lin 2004), it is likely that increasing its activity in the decidua, by increasing Tie-2 expression in hypothyroid animals, can slow vascular regression by the end of gestation, therefore also delaying the delivery.

However, by $19 \mathrm{DG}$, the $\mathrm{T}_{4}$-treated rats also exhibited reduced expression of VEGF and Flk-1 in the decidua and metrial gland. A similar result was also found in the placental disk of $\mathrm{T}_{4}$-treated rats of the same gestational age (Silva et al. 2015). Under normal conditions, VEGF and Flk-1 expression are reduced throughout gestation (Jackson et al. 1994), as we observed in this present study. Furthermore, previous studies have shown that the reduction of placental VEGF expression below physiological levels is related to preterm births in women (Kramer et al. 2005, Chaiworapongsa et al. 2009, Andraweera et al. 2012). One hypothesis is that the reduction of VEGF and Flk-1 in the decidua and metrial gland of rats with excess $\mathrm{T}_{4}$ is one of several mechanisms that can operate to trigger early delivery in hyperthyroid rats (Navas et al. 2011).

\section{CONCLUSIONS}

Hypothyroidism reduces the area of the decidua and increases the expression of VEGF, Tie-2 and Flk-1.

The excess of $\mathrm{T}_{4}$ promotes tissue angiogenesis by increasing the number of vessels in the decidua because of the increased expression of Flk-1.

Acknowledgements.- This study was supported by grants from Fundação de Amparo à Pesquisa de Minas Gerais (Fapemig) and Conselho Nacional de Desenvolvimento Científico e Tecnológico (CNPq).

\section{REFERENCES}

Adelman D.M., Gertssenstein M., Nagy A., Simon M.C. \& Maltepe E. 2000. Placental cell fates are regulated in vivo by HIF-mediated hypoxia responses. Genes Devel. 14:3191-3203.

Ain R., Canham L.N. \& Soares M.J. 2003. Gestation stage-dependent intrauterine trophoblast cell invasion in the rat and mouse: novel endocrine phenotype and regulation. Devel. Biol. 260:176-190.

Andraweera P.H., Dekker G.A., Laurence J.A. \& Roberts C.T. 2012. Placental expression of VEGF family mRNA in adverse pregnancy outcomes. Placenta 33:467-472.

Ashkar A.A. \& Croy B.A. 1999. Interferon- $\gamma$ contributes to the normalcy of murine pregnancy. Biol. Reprod. 61:493-502.

Baker J., Liu J.P., Robertson E.J. \& Efstratiadis A. 1993. Role of insulin-like growth factors in embryonic and postnatal growth. Cell 75:73-82.

Caluwaerts S., Vercruysse L., Luyten C. \& Pijnenborg R. 2005. Endovascular Trophoblast Invasion and Associated Structural Changes in Urterine Spiral Arteries of the Pregnant Rat. Placenta 26:574-584.

Carter A.M. \& Enders A.C. 2004. Comparative aspects of trophoblast development and placentation. Reprod. Biol. Endocrinol. 46(2):1-15.

Carter A.M. \& Mess A. 2007. Evolution of the Placenta in Eutherian Mammals. Placenta 28:259-262.
Carter A.M. 2007. Animal Models of Human Placentation: a review. Placenta 28(Supl.):S41-47.

Chaiworapongsa T., Romero R. \& Tarca A. 2009. A subset of patients destined to develop spontaneous preterm labor has a abnormal angiogenic/anti-angiogenic profile in maternal plasma: Evidence in support of pathophysiologic heterogeneity of preterm labor derived from a longitudinal study. J. Matern. Fetal Neo. M. 22(112):1122-1139.

Chakraborty D., KarimRumi M.A., Konno T. \& Soares M.J. 2011. Natural killer cells direct hemochorial placentation by regulating hypoxia-inducible factor dependent trophoblast lineage decisions. Proc. Natl Acad. Sci. USA 108:16295-16300.

Chakraborty G., Magagna-Poveda A., Parratt C., Umans J.G., Maclusky N.J. \& Scharfman H.E. 2012. Reduced Hippocampal Brain-Derived Neurotrophic Factor (BDNF) in Neonatal Rats after Prenatal Exposure to Propylthiouracil (PTH). Endocrinology 153(3):1311-1316.

Chazara 0., Xiong S. \& Moffett A. 2011. Maternal KIR and fetal HLA-C: a fine balance. J. Leukoc. Biol. 90:703-716.

Cheng S.Y., Leonard J.L. \& Davis P.J. 2010. Molecular aspects of thyroid hormone action. Endocr. Rev. 31(2):139-170.

Coulam C.B. 2000. Understanding the immunobiology of pregnancy and applying it to treatment of recurrent pregnancy loss. Early Pregnancy 4:19-29.

Croy A. 1999. Hasn't the time come to replace the term metrial gland? J. Reprod. Immunol. 42:127-129.

Dilworth M.R. \& Silbley C.P. 2013. Transport across the placenta of mice and women: a review. Placenta 27:S34-S39.

Douglas N.C., Tang H., Gomez R., Pytowski B., Hicklin D.J., Sauer C.M., Kitajewski J., Sauer M.V. \& Zimmermann R.C. 2009. Vascular endothelial growth factor receptor 2 (VEGFR-2) functions to promote uterine decidual angiogenesis during early pregnancy in the mouse. Endocrinology 150:3845-3854.

Enders A.C. \& Blankenship T.N. 1999. Comparative placental structure. Adv. Drug. Deliv. Rev. 38: 3-15.

Favaron P.O., Mess A.M., Oliveira M.F., Gabory A., Miglino M.A., Chavatte-Palmer P. \& Tarrade A. 2013. Morphometric analysis of the placenta in the New World mouse Necromys lasiurus (Rodentia, Cricetidae): a comparison of placental development in cricetids and murids. Reprod. Bio. Endocri. 11:10.

Frederiksen M.C. 2001. Physiologic changes in pregnancy and their effect on drug disposition. Semin. Perinatol. 25(3):120-123.

Freitas E.S., Leite E.D., Souza C.A., Ocarino N.M., Ferreira E., Cassali G.D., Gomes M.G. \& Serakides R. 2007. Histomorphometry and expressions of Cdc47 and Caspase-3 in hyperthyroid rats uteri and placentas during gestation and postpartum associated with fetal development. reprod. Fert. Develop. 19:498-509.

Furukawa S., Kuroda Y. \& Sugiyama A. 2014. A comparison of the histological structure of the placenta in experimental animals. J. Toxicol. Pathol. 27:11-18.

Galton V.A., Martinez E., Hernandez A., St. Germain E.A., Bates J.M. \& St. Germain D.L. 1999. Pregnant rat uterus expresses high levels of the type 3 iodothyronine deiodinase. J. Clin. Invest. 103:979-987.

Galton V.A., Martinez E., Hernandez A., St. Germain E.A., Bates J.M. \& St. Germain D.L. 2001. The type 2 iodothyronine deiodinase is expressed in the rat uterus and induced during pregnancy. Endocrinology 142(5): 2123-2128.

Georgiades P., Ferguson-Smith A.C. \& Burton G.J. 2002. Comparative Development Anatomy of the Murine and Human Definitive Placentae. Placenta 23:3-19.

Gereben B., Zavacki A.M., Ribich S., Kim B.W., Huang S.A., Simonides W.S., Zeöld A. \& Bianco A.C. 2008. Cellular and Molecular Basis of Deiodinase-Regulated Thyroid Hormone Signaling. Endocr. Rev. 29(7):898-938.

Hapon M.B., Simoncini M., Via G. \& Jahn G.A. 2003. Effect of hypothyroidism on hormone profiles in virgin, pregnant and lactating rats, and on lactation. Reproduction 126:371-382.

Harris L.K. \& Aplin J.D. 2007. Vascular remodeling and extracellular matrix 
breakdown in the uterine spiral arteries during pregnancy. Reprod. Sci. $14(8 S): 28-34$.

Hennemann G. 2006. Autonomously functioning thyroid nodules and other causes of thyrotoxicosis, p.2043-2050. In: Hall J.E. (Ed.), Guyton and Hall, Textbook of Medical Physiology. 11th ed. Elsevier Saunders, Philadelphia.

Herington J.L. \& Bany B.M. 2007. Effect the conceptus on uterine natural killer cell numbers and function in the mouse uterus during decidualization. Biol. Reprod. 76:579-588.

Holsberger D.R., Jirawatnoitai S., Kiyokawa H. \& Cooke P.S. 2003. Thyroid hormone regulates the cell cycle inhibitor $\mathrm{p} 27^{\mathrm{kip} 1}$ in postnaltal murine Sertoli cell. Endocrinology 144(9):3732-3738.

Jackson D., Volpert O.V., Bouck N. \& Linzer D.I. 1994. Stimulation and inhibition of angiogenesis by placental proliferin and proliferin-related protein. Science 66:1581-1584.

Jahnke G.D., Choksi N.Y., Moore J.A. \& Shelby M.D. 2004. Thyroid toxicants: assessing reproductive health effects. Environ. Health Perspect. 112(3):363-368.

James J.L., Cartwright J.E., Whitley G.S., Greenhill D.R. \& Hoppe A. 2012. The regulation of trophoblast migration across endothelial cells by low shear stress: consequences for vascular remodeling in pregnancy. Cardiovasc. Res. 93:152-161.

Jauniaux E., Watson A.L., Hempstock J., Bao Y.P., Skepper J.N. \& Burton G.J. 2000. Onset of maternal arterial blood flow and placental oxidative stress. Am. J. Pathol. 157(6):2111-2122.

Kennedy T.G. \& Doktorcik P.E. 1988. Uterine decidualization in hypothysectomized-ovariectomized rats: effects of pituitary hormones. Biol. Reprod. 39:318-328.

Kim M., Park H.J., Seol J.W., Jang J.Y., Cho Y.S., Kim K.R., Choi Y., Lydon J.P., DeMayo F.J., Shibuya M., Ferrara N., Sung H.K., Nagy A., Alitalo K. \& Koh G.Y. 2013. VEGF-A regulated by progesterone governs uterine angiogenesis and vascular remodeling during pregnancy. EMBO Mol. Med. 5:1415-1430.

Kramer B.W., Kaemmerer U., Kapp M., Herbst D., Marx A., Berg D., Groneck P.A. \& Speer C.P. 2005. Decreased expression of angiogenic factors in placentas with chorioamnionitis after preterm birth. Pediatr. Res. 58:607-612.

Lala P.K. \& Chakraborty C. 2003. Factors regulating trophoblast migration and invasiveness: possible derangements contributing to pre-eclampsia and fetal injury. Placenta 24:575-587.

Malassiné A., Frendo J.L. \& Evain-Brion D. 2003. A comparison of placental developmentand endocrine functions between the human and mouse model. Hum. Reprod. Update 9:531-539.

Marcondes F.K., Bianchi F.J. \& Tanno A.P. 2002. Determination of the estrous cycle phases of rats: some helpful considerations. Braz. J. Biol. 62(4A):609-614.

Myatt L. \& Cui X. 2004. Oxidative stress in the placenta. Histochem. Cell Biol. 122:369-382.

Navas P.B., Motta A.B., Hapon M.B. \& Jahn G.A. 2011. Hyperthyroidism advances luteolysis in the pregnant rat through changes in prostaglandin balance. Fertil. Steril. 96:1008-1014.

Ong S.S., Baker M.P.N., Mayhew T.M. \& Dunn W.R. 2005. Remodeling of myometrial radial arteries in preeclampsia. Am. J. Obstet. Gynecol. 192: 572-579.

Pickard M.R., Leonard A.J., Ogilvie L.M., Edwards P.R., Evans I.M., Sinha A.K. \& Ekins R.P. 2003. Maternal hypothyroidism in the rat influences plancetal and liver glycogen stores: fetal growth retardation near term is unrelated to maternal and placental glucose metabolic compromise. J. Endocrinol. 176:247-255.

Picut C.A., Swanson C.L., Parker R.F., Scully K.L. \& Parker G.A. 2009. The metrial gland in the rat and its similarities to granular cell tumor. Toxicol. Pathol. 37:474-480.

Pijnenborg R. \& Vercruysse L. 2010. Animal models of deep trophoblast invasion, p.127-139. In: Pijnenborg R., Brosens I. \& Romero R. (Eds), Placental Bed Disorders. Cambridge University Press, Cambridge.

Pijnenborg R., Dixon G., Robertson W.B. \& Brosens I. 1980. Trophoblastic invasion of human decidua from 8 to 18 weeks of pregnancy. Placenta 1:3-19.

Pijnenborg R., Robertson W.B., Brosens I. \& Dixon G. 1981. Trophoblast invasion and the establishment of haemochorial placentation in man and laboratory animals. Placenta 2:71-91.

Plaisier M. 2011. Decidualisation and angiogenesis. Best Pract. Res. Clin. Obst. Gynaecol. 25:259-271.

Plaisier M., Rodrigues S., Willems F., Koolwijk P., Van Hinsbergh V.W.M. \& Helmerhorst D.M. 2007. Different degrees of vascularisation and their relation to the expression of VEGF, PIGF, angiopoietins and their receptors in first-trimester decidua. Fertil. Steril. 88:176-187.

Ramos C.F. \& Zamoner A. 2014. Thyroid hormone and leptina in the testis. Front. Endocrinol. 5(Art.198):1-12.

Red-Horse K., Zhou Y., Genbacev O., Prakobphol A., Foulk R., McMaster M. \& Fisher S.J. 2004. Trophoblast differentiation during embryo implantation and formation of the maternal-fetal interface. J. Clin. Invest. 114(6):744-754.

Redmer D.A., Aitken R.P., Milne J.S., Reynolds L.P. \& Wallace J.M. 2005. Influence of maternal nutrition on messenger RNA expression of placental angiogenic factors and their receptors at midgestation in adolescent sheep. Biol. Reprod. 72:1004-1009.

Reynolds L.P., Borowicz P.P., Caton J.S., Vonnahme K.A., Luther J.S., Buchanan D.S., Hafez S.A., Grazul-Bilska A.T. \& Redmer D.A. 2010. Uteroplacental vascular development and placental function: an update. Int. J. Devel. Biol. 54:355-365.

Seidenspinner T., Tetens J., Habier D., Bennewitz J. \& Thaller G. 2010. The placental growth factor (PGF): a positional and functional candidate gene influencing calving ease and stillbirth in German dairy cattle. Anim. Gene. Immunog. Mol. Gen. Funct. Genol. 42:22-27.

Serakides R., Nunes V.A., Nascimento E.F., Ribeiro A.F.C. \& da Silva C.M. 2001. Foliculogênese e esteroidogênese ovarianas em ratas adultas hipertireóideas. Arq. Bras. Endocrinol. Metab. 45:258-264.

Sherer D.M. \& Abulafia 0. 2001. Angiogenesis during implantation, and placental and early embryonic development. Placenta 22:1-13.

Shortman K. \& Liu Y.J. 2002. Mouse and human dendritic cell subtypes. Nature Rev. 2:151-161.

Silva C.M., Serakides R., Oliveira T.S., Ocarino N.M., Nascimento E.F. \& Nunes V.A. 2004. Histomorfometria e histoquímica dos ovários, tubas e útero de ratas hipotireoideas em metaestro-diestro. Arq. Bras. Med. Vet. Zootec. 56:628-639.

Silva J.F. \& Serakides R. 2016. Intrauterine trophoblast migration: A comparative view of humans and rodents. Cell Adhesion Migration 10:123.

Silva J.F., Ocarino N.M. \& Serakides R. 2014. Maternal thyroid dysfunction affects placental gene profile of inflammatory mediators and the intrauterine trophoblast migration kinetics. Reproduction 147:803816.

Silva J.F., Ocarino N.M. \& Serakides R. 2015. Placental angiogenic and hormonal factors are affected by thyroid hormones in rats. Pathol. Res. Pract. 211:226-234.

Silva J.F., Ocarino N.M., Vieira A.L.S., Nascimento E.F. \& Serakides R. 2013. Effects of hypo- and hyperthyroidism on proliferation, angiogenesis, apoptosis and expression of COX-2 in the Corpus luteum of female rats. Reprod. Dom. Anim. 48:691-698.

Silva J.F., Vidigal P.N., Galvã D.D., Boeloni J.N., Nunes P.P., Ocarino N.M., Nascimento E.F. \& Serakides R. 2012. Fetal growth restriction in hypothyroidism is associated with changes in proliferative activity, apoptosis and vascularisation of the placenta. Reprod. Fertil. Devel. 24(7):923931.

Smith S.D., Dunk C.E., Aplin J.D., Harris L.K. \& Jones R.L. 2009. Evidence for Immune Cell Involvement in Decidual Spiral Arteriole Remodeling in early Human Pregnancy. Am. J. Pathol. 174(5):1959-1971.

Soares M.J., Chakraborty D., Karim Rumi M.A., Konno T. \& Renaud S.J. 2012. Rat placentation: an experimental model for investigating the hemochorial maternal-fetal interface. Placenta 33:233-243. 
Toder V., Fein A., Carp H. \& Torchinsky A. 2003. TNF-alpha in pregnancy loss and embryo maldevelopment: a mediator of detrimental stimuli or a protector of the fetoplacental unit? J. Assist. Reprod. Genet. 20:73-81.

Torry D.S., Hinrichs M. \& Torry R.J. 2004. Determinants of placental vascularity. Am. J. Reprod. Immunol. 51:257-268.

Vasilopoulou E., Loubière L.S., Lash G.E., Ohizua O., McCabe C.J., Franklyn J.A., Kilby M.D. \& Chan S.Y. 2014. Triiodothyronine regulates angiogenic growth factor and cytokine secretion by isolated human decidual cells in a cell-type human decidual cells in a cell-type specific and gestational age-dependent manner. Hum. Reprod. 1(0):1-12.

Vercruysse L., Caluwaerts S., Luyten C. \& Pijenenborg R. 2006. Interstitial trophoblast invasion in the decidua and mesometrial triangle during the last third of pregnancy in the rat. Placenta 27:22-23.

Vonnahme K.A., Evoniuk J., Johnson M.L., Borowicz P.P., Luther J.S., Pant D., Redmer D.A., Reynolds L.P. \& Grazul-Bilska A.T. 2008. Placental vascu- larity and growth factor expression in singleton, twin, and triplet pregnancies in the sheep. Endocrinology 33:53-61.

Vonnahme K.A., Zhu M.J., Borowicz P.P., Geary T.W., Hess B.W., Reynolds L.P., Caton J.S., Means W.J. \& Ford S.P. 2007. Effect of early gestational undernutrition on angiogenic factor expression and vascularity in the bovine placentome. J. Anim. Sci. 85:2464-2472.

Yuan K. \& Lin M.T. 2004. The roles of vascular endothelial growth factor and angiopoietin-2 in the regression of pregnancy pyogenic granuloma. Oral Dis. 10:179-185.

Zanatta A.P., Zanatta L., Gonçalves R., Zamoner A. \& Silva F.R.M.B. 2013. Integrin participates in the effect of thyroxine on plasma membrane in immature rat testis. BBA-Gen. Subjects 1830:2629-2637.

Zhang J., Sun R., Wei H., Wu D. \& Tian Z. 2007. Toll-like receptor 3 agonist enhances IFN-gamma and TNF-alpha production by murine uterine NK cells. Int. Immunopharmacol. 7:588-596. 